\title{
1 Biofilm Derived Oxylipin Mediated Autoimmune Response in Breast
}

\section{Implant Subjects}

3 Imran Khan ${ }^{1}$, Robert E. Minto ${ }^{2}$, Christine Kelley-Patteson ${ }^{3}$, Bruce W. Van Natta ${ }^{3}$, Colby R.

4 Neumann ${ }^{1}$, Lily J. Suh ${ }^{1}$, Kanhaiya Singh ${ }^{1}$, Mary Lester $^{4}$, R Jason VonDerHaar ${ }^{4}$, Gayle M. Gordillo ,

$5 \quad$ Aladdin H. Hassanein ${ }^{1}$, Chandan K. Sen ${ }^{1}$, Marshall E. Kadin ${ }^{5,6}$, Mithun Sinha ${ }^{1 *}$

$7 \quad{ }^{1}$ Indiana Center for Regenerative Medicine and Engineering, Department of Surgery, Division of

8 Plastic Surgery, Indiana University School of Medicine, Indianapolis, Indiana, USA

$9{ }^{2}$ Department of Chemistry and Chemical Biology, Indiana University-Purdue University

10 Indianapolis, Indianapolis, Indiana

$11{ }^{3}$ Meridian Plastic Surgeons, Indianapolis, Indiana

$12{ }^{4}$ Division of Plastic Surgery, Department of Surgery, Indiana University School of Medicine, 13 Indianapolis, Indiana,

$14{ }^{5}$ Department of Dermatology, Roger Williams Medical Center, Boston University School of Medicine, Providence, Rhode Island, USA

${ }^{6}$ Warren Alpert School of Medicine, Brown University, Providence, Rhode Island

*Corresponding Author: Mithun Sinha, PhD; mitsinha@iu.edu

Address:

$$
975 \text { W Walnut St, }
$$$$
\text { Medical Research Library Building, Suite \# 444A }
$$$$
\text { Indiana University School of Medicine }
$$$$
\text { Indianapolis, IN } 46202 .
$$

Tel. 3172782713

Fax. 3172782708

Short Title: Biofilm mediated autoimmune response 
medRxiv preprint doi: https://doi.org/10.1101/2020.11.18.20233510; this version posted November 20, 2020. The copyright holder for this preprint (which was not certified by peer review) is the author/funder, who has granted medRxiv a license to display the preprint in perpetuity.

It is made available under a CC-BY-NC-ND 4.0 International license .

\section{Abstract}

27 Over 10 million women worldwide have breast implants for breast cancer/prophylactic

28 reconstruction or cosmetic augmentation. In recent years, a number of patients have described a

29 constellation of symptoms that are believed to be related to their breast implants. This

30 constellation of symptoms has been named Breast Implant IIIness (BII). The symptoms described

31 include chronic fatigue, joint pain, muscle pain and a host of other manifestations often associated

32 with autoimmune illnesses. In this work, we report that bacterial biofilm is associated with BII. We

33 postulate that the pathogenesis of BII is mediated via a host-pathogen interaction whereby the

34 biofilm bacteria Staphylococcus epidermidis interacts with breast lipids to form the oxylipin 10-

35 HOME. The oxylipin 10-HOME was found to activate CD4 ${ }^{+}$T cells to Th1 subtype. An increased

36 abundance of $\mathrm{CD} 4^{+}$Th1 was observed in the breast tissue of Bll subjects. The identification of a

37 mechanism of immune activation associated with Bll via a biofilm enabled pathway provides

38 insight into the pathogenesis for implant-associated autoimmune symptoms. 
medRxiv preprint doi: https://doi.org/10.1101/2020.11.18.20233510; this version posted November 20, 2020. The copyright holder for this preprint (which was not certified by peer review) is the author/funder, who has granted medRxiv a license to display the preprint in perpetuity.

It is made available under a CC-BY-NC-ND 4.0 International license .

46

47 Breast implants were first introduced in 1962. Nearly 60 years later, their safety has continued to

\section{Introduction}

be controversial in the medical field, including a period of FDA-mandated restrictions on the use of silicone gel breast implants in the U.S. in the $1990 \mathrm{~s}^{1,2}$. Nearly 300,000 women have breast implant surgeries every year in the United States, for reasons including cosmetic augmentation, post-mastectomy breast reconstruction (breast cancer and prophylactic mastectomy), revision of prior augmentation/ reconstruction, and gender affirmation ${ }^{3}$. A subset of patients with breast implants have a myriad of nonspecific systemic symptoms ${ }^{4,5}$. The symptoms described include fever, myalgias, chronic fatigue, arthralgias and a host of other manifestations often associated with autoimmune illnesses ${ }^{6-12}$. This constellation of symptoms related to implants has been named Breast Implant IIIness (BII). The number of patients who opt for breast implant explantation due to complications including breast implant illness is over 30,000 annually ${ }^{3}$. Thus, BII is a growing concern to both patients and surgeons alike with more than 10 million women worldwide currently having breast implants ${ }^{6}$. Despite the increased concern regarding BII, existing scientific literature doesn't show a definite link between breast implants and autoimmune or connective tissue diseases. Some epidemiological studies have reported that women with silicone gel-filled implants were 8 times more likely to be diagnosed with Sjögren syndrome, an autoimmune disorder characterized by dry eyes and a dry mouth. Also, such subjects are 7 times more likely to be diagnosed with scleroderma, a group of autoimmune diseases that cause the skin and connective tissues to become hard and tighten, and nearly 6 times more likely to be diagnosed with rheumatoid arthritis ${ }^{8}$. Other studies have reported an association of autoimmune symptoms with breast implants ${ }^{7,9-12}$. Symptoms have been documented to begin after placement of the implant and are often relieved by their explantation ${ }^{13,14}$. This led patients and physicians to suspect that the breast implants are the likely cause ${ }^{13,14}$. However, FDA mandated studies have found silicone gel breast implants to be safe ${ }^{15}$. Of note to this apparent contradiction is the fact that 
medRxiv preprint doi: https://doi.org/10.1101/2020.11.18.20233510; this version posted November 20, 2020. The copyright holder for this preprint (which was not certified by peer review) is the author/funder, who has granted medRxiv a license to display the preprint in perpetuity.

It is made available under a CC-BY-NC-ND 4.0 International license .

71 these symptoms have been reported in subjects with other implants such as orthopedic

72 arthroplasty which is typically comprised of titanium ${ }^{16-20}$. This indicates that the underlying cause

73 of these conditions may be associated with factors other than the implant material. Therefore, it

74 is important to decipher the underlying molecular mechanism associated with BII for a better

75 understanding in the future of all implant-related illnesses with autoimmune manifestations.

76 This is the first in depth study to investigate the possible role of bacterial biofilm as a factor in the

77 pathogenesis of BII through a patient-based study with a mechanistic pathway. We have identified

78 a biofilm-derived oxylipin in increased abundance in Bll subjects. The oxylipin led to activation of

$79 \mathrm{CD}^{+}$Th1 cells in an in vitro and in vivo mouse model suggesting a role in the establishment of 80 an autoimmune response often observed to be associated with BII.

81

82

\section{Results}

\section{Bacterial Biofilm in Implant-Associated with Bll}

The study included 68 patients. Forty-six patients with Bll were analyzed. Subjects were diagnosed with Bll using clinical parameters outlined in previous studies ${ }^{6-12}$ (Fig. 1A) . As a part of the diagnosis, the patients were required to complete a questionnaire (Supplementary Table 1). The questionnaire screened for the commonly reported symptoms associated with BII ${ }^{6-12}$. Implant, associated capsules and breast tissue were collected from these subjects (Fig. 1B-C) as described in methods. The mean age of Bll patients was 44.0 years with mean duration of implant insertion of 11.51 years. Two groups were considered as controls. Control group I (nonBII, $n=14$ ) was comprised of patients with breast implants who didn't exhibit Bll symptoms but went through explantation of the breast implant. The mean age of non-BII patients was 46.5 years. Control group II (normal tissue, $n=8$ ) was comprised of patients without an implant, whose breast tissue was removed as a clinically indicated surgical procedures e.g., (breast reduction surgery, 
medRxiv preprint doi: https://doi.org/10.1101/2020.11.18.20233510; this version posted November 20, 2020. The copyright holder for this preprint (which was not certified by peer review) is the author/funder, who has granted medRxiv a license to display the preprint in perpetuity.

It is made available under a CC-BY-NC-ND 4.0 International license .

mammoplasty, contralateral procedures for reconstruction symmetry and mastopexy). The mean age of normal subjects was 26.8 years. The demographics of the subjects have been provided in

\section{Supplementary Table 2.}

Bacterial biofilm was observed in implant-associated capsules through scanning electron microscopy (Fig. 1D, Supplementary Fig. S1A). Though biofilm was detected in the capsules of implants from both BII and non-BII patients, the abundance of biofilm was significantly more in the capsules of Bll subjects as observed through wheat germ agglutin (WGA) assay (Fig 1E-F). The microbiological culture analyses of the tissues resulted in no growth of bacterial colonies (data not shown). It has been reported that bacterial biofilms are difficult to detect through colony forming assays due to their subdued metabolism ${ }^{21,22}$. Hence, in cases of bacterial biofilm, next generation sequencing (NGS) using variable region of bacterial 16S rRNA gene are employed to type bacteria and determine their abundance ${ }^{23}$. Diverse types of biofilm forming bacteria were observed associated with BII, non-BII and normal tissues (Fig. 1G-I) through next generation sequencing (NGS) of the 16S rRNA variable region. Most of the species identified were opportunistic bacteria associated with normal skin flora capable of forming biofilms. (Fig. 1G-I). Comparative analyses with the normal, non-BII and BII groups revealed an increased abundance of Staphylococcus epidermidis in BII (Fig. 1J). The other bacteria found in increased abundance in breast tissue was Cutibacterium acnes. Bivariate analysis using cross-tabulation was performed between presence of biofilm and the study groups. Using the Fisher's exact test, Staphylococcus epidermidis colonization was observed to be significantly higher $(p<0.001)$ in the BII group (63.04\%) compared to non-BII group (14.3\%) and the normal group. Using exact logistic regression, the Bll group was 9.8 times significantly more likely to have $S$. epidermidis colonization compared to the non-BII group $(p=0.003)$. Similarly, when comparing with normal groups, the Bll group was 17.4 times significantly more likely to have $S$. epidermidis $(p=0.0021)$. C. acnes was not found to be associated (Fisher's exact $p$-value $=0.116$ ) with the groups defined 
medRxiv preprint doi: https://doi.org/10.1101/2020.11.18.20233510; this version posted November 20, 2020. The copyright holder for this preprint (which was not certified by peer review) is the author/funder, who has granted medRxiv a license to display the preprint in perpetuity.

It is made available under a CC-BY-NC-ND 4.0 International license .

120 in the study. However, though not significant, the Bll group (80.4\%) tended to show 4 times higher

121 odds of colonization with C.acnes (Odds ratio from exact logistic regression=3.98 [95\% $\mathrm{Cl}$ : 0.32 ,

122 26.10, $p=0.1684]$ ) compared to the normal (50.0\%) group (Fig. 1J, Supplementary Fig. S1B).

123 Increased Abundance of Biofilm Derived 10-HOME in BII Subjects

124 The oxylipin (10)-hydroxy-(8E)-octadecenoic acid (10-HOME) is formed by the bacterial oxidation

125 of oleic acid (Fig. 2A). The oxylipin 10-HOME has been reported to inhibit flagellum-driven

126 swimming and swarming motilities and stimulate the formation of bacterial biofilms in vitro ${ }^{24}$. The

127 oxylipin 10-HOME was synthesized in the laboratory (commercially not available) in natural

128 isotopic abundance (light) isotope and deuterated (heavy) isotope forms. The former was used

129 for biological experiments, whereas the later was used as a liquid chromatography-mass

130 spectrometry (LC-MS) standard. The synthesized 10-HOME was validated through thin layer

131 chromatography and NMR spectroscopy (Supplementary Fig. S2A-B).

132 Elevated levels of 10-HOME in implant-associated samples of BII compared to non-BII samples 133 were observed through mass spectrometry (Fig. 2B-D). Positive correlation was observed 134 between bacterial abundance and concentration of 10-HOME in Bll subjects (Fig. 2E). Similar 135 correlation was observed in Bll subjects with Staphylococcus epidermidis (Fig. 2F). To determine 136 if S. epidermidis was capable of synthesizing 10-HOME, it was cultured in vitro with oleic acid as 137 a source of carbon. Formation of 10-HOME was detected using gas chromatography-mass 138 spectrometry (Fig. 2G). Oxylipins have been reported to cause CD4 ${ }^{+}$T cell activation ${ }^{25}$. Hence, 139 we explored the role of $\mathrm{CD}^{+} \mathrm{T}$ cells in Bll.

140 Abundance of CD4 ${ }^{+}$Th1 Cells in Implant-Associated Tissue of Bll Subjects

141 Breast tissue associated with the implant of Bll subjects showed increased presence of CD4 ${ }^{+}$

$142 \mathrm{~T}-\mathrm{BET}^{+} \mathrm{T}$ cells compared to that of non-Bll breast tissue (Fig. 3A). T-BET transcription factor is 143 critical in Th1 subtype determination ${ }^{26}$. Th1 cells are associated with an auto-immune response 
medRxiv preprint doi: https://doi.org/10.1101/2020.11.18.20233510; this version posted November 20, 2020. The copyright holder for this preprint (which was not certified by peer review) is the author/funder, who has granted medRxiv a license to display the preprint in perpetuity.

It is made available under a CC-BY-NC-ND 4.0 International license .

144 in multiple illnesses including rheumatoid arthritis ${ }^{27}$. The $\mathrm{CD}^{+}$Th1 cells associated with BII

145 subjects also were CD36 ${ }^{+}$(Fig. 3B). CD36 is a fatty acyl translocase ${ }^{28}$; its level is upregulated

146 when uptake of fatty acid (normal or oxidized) is required. It is to be noted that BII is a systemic

147 autoimmune manifestation. Hence, the peripheral blood of BII and non-Bll subjects was analyzed

148 for $\mathrm{CD}^{+} \mathrm{T}$ cells (Th1, Th2, Th9 and Th22). Increased abundance of Th1 cells was observed in

149 Bll subjects $(\mathrm{N}=9)$ as measured through flow cytometry using CD183/CXCR3 (CD4 ${ }^{+}$Th1 cell

150 marker) (Fig. 3C). No significant difference was observed in the abundance of other Th subtypes

151 Th2 (CD194), Th9 (CD196) and Th22 (CD196) between Bll subjects and non-BIl subjects

152 (Supplementary Fig. S3A-B). The following human cell lines were used as positive control for 153 validation of surface antigens. Mac2A for CD183, Mac2B for CD194 ${ }^{29}$ and TLBR1 for CD196 30

154 (Supplementary Fig. S3C-E). These results, however, don't definitively establish that 10-HOME 155 led to $\mathrm{CD} 4^{+} \mathrm{Th} 1$ cell induction or that $10-\mathrm{HOME}$ can lead to CD36 upregulation. Thus, we studied the effect of 10-HOME on human primary naïve $\mathrm{CD} 4^{+} \mathrm{T}$ cells.

\section{Oxylipin 10-HOME Polarizes Naïve CD4+ T Cells to Th1 Subtype in vitro}

In order to study the effect of $10-\mathrm{HOME}$ on $\mathrm{T}$ cells, naïve $\mathrm{CD} 4^{+} \mathrm{T}$ cells (isolated from human peripheral blood mononuclear cells) were treated with $100 \mu \mathrm{M}$ 10-HOME for 48h. Increased CD36

(Fig. 4A), flow cytometry (Fig. 4B) and quantitative real time PCR (Fig. 4H) indicative of the 10transcription factor activated during the polarization of naïve T cells to Th1 subtype $\left.{ }^{26}\right)\left(\mathbf{F i g} . \mathbf{4 C}_{\text {, }}\right.$ 
medRxiv preprint doi: https://doi.org/10.1101/2020.11.18.20233510; this version posted November 20, 2020. The copyright holder for this preprint (which was not certified by peer review) is the author/funder, who has granted medRxiv a license to display the preprint in perpetuity.

It is made available under a CC-BY-NC-ND 4.0 International license .

168

169

170

171

172

173

174

175

176

177

178

179

180

181

182

183

184

185

186

187

188

189

190

secreted pro-inflammatory cytokine IFN-y through ELISA (Fig. 4E). The CD183+ Th1 cells exhibited increased abundance of CD36 marker (Supplementary Fig. 4B). The other subtypes of CD4 ${ }^{+}$T cells (Th2, Th9 and Th22) assayed didn't exhibit any statistically significant increase in abundance post $10-\mathrm{HOME}$ treatment on naïve $\mathrm{CD}^{+} \mathrm{T}$ cells. Th2 cells were assayed using surface marker CD194/CCR4 (Supplementary Fig. 4C), transcription factor GATA3 (Supplementary Fig. 4D) and anti-inflammatory cytokines IL 4 and IL10 (Fig. 4F-G). Th9 and Th22 cells were assayed using surface marker CD196/CCR6 (Supplementary Fig. 4E).

\section{Elevated CD4 ${ }^{+}$Th1 in Peripheral Blood of Mice Administered with 10-HOME}

To test if 10-HOME can induce Th1 cells in vivo, we administered 10-HOME into the abdominal mammary fat pad of mice (Fig. 5A) as described in the Methods. An increased abundance of $\mathrm{CD}^{+}$Th1 cells was found in the murine blood 14 days post administration of 10-HOME (Fig. 5B). Other subtypes of $\mathrm{CD}^{+} \mathrm{T}$ cells (Th2) didn't exhibit any statistically significant increase in abundance (Fig. 5C).

\section{Discussion}

Biofilm formation enables single-cell microbes to assume a temporary multicellular lifestyle, in which "group behavior" facilitates survival in adverse environments ${ }^{31}$. The transition from planktonic growth (associated with acute pathogenic infections) to biofilm occurs in response to environmental changes, and involves multiple regulatory networks thereby mediating the spatial and temporal reorganization of the bacterial cell ${ }^{31}$. Bacterial biofilms have been implicated to cause gastric cancer by Helicobacter pylori ${ }^{32}$, colon cancer $^{33}$, 34, breast implant-associated anaplastic large cell lymphoma (BIA-ALCL) and chronic inflammation ${ }^{35-37}$. The factors that involve 
medRxiv preprint doi: https://doi.org/10.1101/2020.11.18.20233510; this version posted November 20, 2020. The copyright holder for this preprint (which was not certified by peer review) is the author/funder, who has granted medRxiv a license to display the preprint in perpetuity.

It is made available under a CC-BY-NC-ND 4.0 International license .

191 interplay between host and pathogen are influenced by the micro-environmental niche where the

192 bacteria reside $22,38,39$. Breast implants provided a conducive surface for the adherence and growth

193 of bacterial biofilms ${ }^{40}$. The breast is a modified sweat gland, with multiple external opening from

194 the mammary ducts via the nipple, providing a passage for microbes (normal skin flora) to the

195 breast tissue. This concept has been supported by a report whereby researchers have shown the

196 presence of microbes deep inside the breast tissue ${ }^{41}$. Many bacteria belonging to the normal

197 microflora of the body have been reported to form bacterial biofilms ${ }^{42}$. Pseudomonas

198 aeruginosa ${ }^{43,44}$, Staphylococcus aureus ${ }^{45}$ and Ralstonia picketii ${ }^{40,46}$ are some of the common

199 biofilm forming species associated with breast implants. The bacterial biofilms are difficult to

200 detect since they have subdued metabolism and may not be detectable as CFUs in standard

201 microbiological assays 21, 22. They can be identified through structural assays like scanning

202 electron microscopy $(\mathrm{SEM})^{22,47}$ and genetic assays (e.g.,16S rRNA sequencing $)^{48}$. The

203 observation in this study of increased abundance of bacterial biofilm comprised of Staphylococcus

204 epidermidis associated with implant-associated tissue of Bll patients relative to controls was thus

205 critical in understanding to the potential pathology of BII. It is to be noted that while this study was

206 being performed, anecdotal evidence of S.epidermidis with Bll was reported by Mark et al ${ }^{49}$.

207 The oxidation of fatty acids is one of the main biochemical reactions in the synthesis of lipid

208 mediators. The oxygenation of unsaturated fatty acids leads to the formation of oxylipins, although

209 free fatty acids are not readily available as they are found as triglycerides. The action of bacterial

210 lipases, such as dioxygenases (DOX) and lipoxygenases (LOX) on breast adipose result in the

211 availability of free fatty acids. When oleic acid is used as a bacterial substrate, it is oxidized to

212 form 10-HOME. The unique adipose tissue found in breast tissue is rich in oleic acid containing

213 lipids ${ }^{50,51}$. The oxylipin 10-HOME has been reported to promote bacterial biofilms in vitro ${ }^{24}$. The

214 increased abundance of 10-HOME in our study associated with breast tissues of Bll subjects thus 
medRxiv preprint doi: https://doi.org/10.1101/2020.11.18.20233510; this version posted November 20, 2020. The copyright holder for this preprint (which was not certified by peer review) is the author/funder, who has granted medRxiv a license to display the preprint in perpetuity.

It is made available under a CC-BY-NC-ND 4.0 International license .

215 provides evidence that breast microflora may interact with breast lipids promoting the formation

216 of bacterial biofilms.

217 Oxylipins are also known to be immune-modulatory. It has been reported that 12,13 DiHOME 218 derived from oxidation of linoleic acid led to the reduction of regulatory T cells (Tregs), impeded 219 immune tolerance and promoted childhood atopy and asthma ${ }^{25}$. Elevated levels of 10-HOME 220 formed due to bacterial biofilms could lead to immune cell activation. Reports suggest that CD4 ${ }^{+}$

221 T cells are activated due to the persistent presence of a bacterial biofilm ${ }^{52,53}$. CD4 ${ }^{+} \mathrm{T}$ cells play 222 an important role in the pathogenesis of chronic systemic inflammatory autoimmune diseases 223 such as multiple sclerosis, diabetes and rheumatoid arthritis ${ }^{54-56}$. CD4 ${ }^{+} \mathrm{T}$ cells can be divided into 224 Th1, Th2, Th9, Th17 and Th22 subsets based upon the cytokines they produce. In chronic 225 inflammatory systemic autoimmune diseases such as diabetes, multiple sclerosis and rheumatoid 226 arthritis, Th1 cells were found to be involved ${ }^{57}$. It is to be noted that many of the symptoms of BII 227 patients were similar to rheumatoid arthritis and multiple sclerosis ${ }^{8}$. Th1 cells trigger delayed type 228 hypersensitivity (DTH) reactions (which are mostly mediated by macrophages) and 229 immunoglobulin class switch towards $\lg G 2 a^{55,56}$.

230 Oxidized lipids have been associated with pain and inflammatory conditions ${ }^{58}$. Pain reported as 231 arthralgia and myalgia are common in Bll. We identified increased presence of CD4 ${ }^{+}$Th1 cells 232 in the breast tissue and peripheral blood of Bll subjects. Findings of this study demonstrate that 233 10-HOME was capable of polarizing naïve CD4 ${ }^{+} \mathrm{T}$ cells towards Th1 subtype in vitro. Increased 234 abundance of transcription factor T-BET required for Th1 fate was identified post 10-HOME 235 treatment. The polarization to Th1 subtype was also supported by the observation of increased 236 expression of pro-inflammatory cytokine IFN-y secreted by Th1 cells. Systemic analyses in our 237 study didn't revealed polarization towards Th2, Th9 and Th22 subtypes. It is to be noted that the 238 current work does not rule out the polarization of naïve CD4 ${ }^{+} \mathrm{T}$ cells to Th17 subtype upon 
medRxiv preprint doi: https://doi.org/10.1101/2020.11.18.20233510; this version posted November 20, 2020. The copyright holder for this preprint (which was not certified by peer review) is the author/funder, who has granted medRxiv a license to display the preprint in perpetuity.

It is made available under a CC-BY-NC-ND 4.0 International license .

239 treatment with 10-HOME. Th17 subtype has been also reported to be associated with auto-

240 immune syndrome ${ }^{59}$.

241 To correlate the association of $10-\mathrm{HOME}$ with activation of $\mathrm{CD}^{+} \mathrm{T}$ cells in vivo, mice were

242 administered with 10-HOME in their mammary fat pad. An increased abundance of CD4 ${ }^{+}$Th1

243 cells in peripheral circulation in 10-HOME administered mice was observed. These observations

244 also help to explain the increased abundance CD4 ${ }^{+}$Th1 in the BII subjects.

245 Taken together, we investigated the biofilm hypothesis of breast implant illness through a host-

246 pathogen interaction. The breast microenvironment led to formation of biofilm derived 10-HOME

247 from host oleic acid. The 10-HOME thus formed led to activation of CD4 ${ }^{+}$Th1 cells in vitro and in

248 vivo. The study provides the first evidence of a possible link of biofilm derived 10-HOME inducing

249 an autoimmune response in patients with BII. Additionally, in light of reports of biofilm association

250 with metal implants such as orthopedic arthroplasty, this study provides an explanation of

251 autoimmune responses reported using those metal implants ${ }^{16-20}$. The findings of this study

252 suggest that management of biofilm can help to increase the safety and long-term use of implants.

253 Further research needs to be conducted to elucidate if other biofilm forming bacterial species are

254 involved in the pathogenesis of BII. Also, more investigation is warranted to decipher the pathway

255 leading to the onset of BII post-biofilm formation and the involvement of other biofilm derived

256 metabolites.

258 Materials and Methods

259 Human subjects. Subjects participating in the study were patients diagnosed with Bll.

260 Demographic characteristics of patients presented in (Supplementary Table 2). All human 
medRxiv preprint doi: https://doi.org/10.1101/2020.11.18.20233510; this version posted November 20, 2020. The copyright holder for this preprint (which was not certified by peer review) is the author/funder, who has granted medRxiv a license to display the preprint in perpetuity.

It is made available under a CC-BY-NC-ND 4.0 International license .

261 studies were approved by The Indiana University School of Medicine Institutional Review Board.

262 Declaration of Helsinki protocols was followed, and patients gave their written informed consent.

263 Animals. All animal (mice) experiments were approved by the Indiana University School of

264 Medicine Institutional Animal Care and Use Committee (SoM-IACUC) under protocol 19102 -

265 Murine model of breast implant diseases. Animals were housed under a 12-h light-dark cycle with

266 food and water ad libitum.

267 Bacterial strains. Staphylococcus epidermidis (Winslow and Winslow) Evans (ATCC $₫ 35984^{\mathrm{TM}}$ )

268 were grown on tryptic soy agar plate at $37^{\circ} \mathrm{C}$.

269 Scanning Electron Microscope Imaging. The samples were collected in glutaraldehyde fixation

270 buffer, dehydrated with graded ethanol, and treated with hexamethyldisilazane (HMDS, Ted Pella

271 Inc.) and left overnight for drying ${ }^{22,38}$. Before scanning, samples were mounted and coated with

272 gold. Samples were imaged with $\mathrm{FEI}{ }^{\mathrm{TM}}$ NOVA nanoSEM scanning electron microscope $\left(\mathrm{FEI}^{\mathrm{TM}}\right.$,

273 Hillsboro, OR) equipped with a field-emission gun electron source.

274 Wheat-germ agglutinin (WGA) staining. Paraffin embedded capsules surrounding the implant

275 were sectioned on the slide. Wheat Germ Agglutinin, Alexa Fluor ${ }^{\mathrm{TM}} 488$ Conjugate (Invitrogen)

276 stock solution $(1 \mathrm{mg} / \mathrm{ml})$ was diluted in PBS. The sections were stained with Wheat Germ

277 Agglutinin (dilution 1:200) for 10 mins ${ }^{60}$. The slides were then mounted and imaged on a Zeiss

278 LSM 880 microscope equipped with the AIRYscan detector.

NGS sequencing for $16 S$ rRNA. Microbial DNA in each sample were sequenced by MicrogenDx

280 Inc using the Illumina MiSeq sequencer. Forward and reverse primers were used to detect and

281 amplify the target sequence, for $16 \mathrm{~S}$ gene in bacteria. The samples are differentiated from each

282 other when run on the MiSeq sequencer by a "tag," a unique identifying sequence attached to the

283 forward and reverse primers implemented when the targeted sequence is amplified using PCR.

284 Following PCR, purification of the pooled DNA was done by removing small fragments using both 
medRxiv preprint doi: https://doi.org/10.1101/2020.11.18.20233510; this version posted November 20, 2020. The copyright holder for this preprint (which was not certified by peer review) is the author/funder, who has granted medRxiv a license to display the preprint in perpetuity.

It is made available under a CC-BY-NC-ND 4.0 International license .

Agencourt Ampure beads and Qiagen Minelute kit. The DNA was quantified and prepared for sequencing. Finally, the DNA library was run on the MiSeq sequencer. The sequencing reads were analyzed for quality and length during the data analysis. The data analysis pipeline consisted of two major stages, the denoising and chimera detection stage and the microbial diversity analysis stage. During the denoising and chimera detection stage, denoising was performed using various techniques to remove short sequences, singleton sequences, and noisy reads. With the low-quality reads removed, chimera detection was performed to aid in the removal of chimeric sequences. The high-quality sequencing reads of the variable region of $16 \mathrm{~S}$ rRNA were compared to curated database of MicrogenDx. The database is comprised of 18500 unique bacteria.

Synthesis of 10-HOME. For the synthesis of 10-HOME, a convergent Horner-WadsworthEmmons approach was employed. Indiana University has filed a provisional patent application (Application \# 63/107,626) on behalf of REM, IK and MS relating to the methods and synthesis of 10-HOME and its deuterated $17,17,18,18,18 d_{5}$ analog to be used as analytical standards.

Primary T-cell isolation. Naïve $\mathrm{CD}^{+} \mathrm{T}$ cells were isolated from peripheral blood mononuclear cells (PBMC). Briefly, PBMCs were isolated by Ficoll-Paque PLUS density gradient sedimentation. Naïve $\mathrm{CD}^{+} \mathrm{T}$ cells were then enriched using immunomagnetic, column-free, negative selection (Naïve CD4 T cell isolation kit, Miltenyi Biotec) ${ }^{61}$. Unwanted cells (CD8, CD14, CD15, CD16, CD19, CD25, CD34, CD36, CD45RO, CD56, CD123, TCRү/ठ, HLA-DR, and CD235a (Glycophorin A)) were removed using antibody complexes recognizing non-naïve CD4 T cells and dextran-coated magnetic particles.

Primary $\mathrm{CD4}^{+} \mathrm{T}$ cell culture and $10-\mathrm{HOME}$ treatment. Primary $\mathrm{CD} 4^{+} \mathrm{T}$ cells were cultured under standard conditions at $37^{\circ} \mathrm{C}$ in a humidified incubator with $5 \% \mathrm{CO}_{2}$ in RPMI-1640 growth medium supplemented with $10 \%$ FBS, $100 \mathrm{lU} / \mathrm{ml}$ penicillin, $0.1 \mathrm{mg} / \mathrm{ml}$ streptomycin, $10 \mathrm{mmol} / \mathrm{l} \mathrm{L-glutamine}$ 
medRxiv preprint doi: https://doi.org/10.1101/2020.11.18.20233510; this version posted November 20, 2020. The copyright holder for this preprint (which was not certified by peer review) is the author/funder, who has granted medRxiv a license to display the preprint in perpetuity.

It is made available under a CC-BY-NC-ND 4.0 International license .

309

310

311

312

313

314

315

316

317

318

319

320

321

322

323

324

325

326

327

328

329

330

331

332

333

supplemented with IL2 for $48 \mathrm{~h}^{62}$. Following that, $\mathrm{CD} 4^{+} \mathrm{T}$ cells were treated with oxylipin 10-HOME $(100 \mu \mathrm{M})$ or vehicle control for $48 \mathrm{~h}$.

Immunohistochemistry and immunocytochemistry. Paraffin embedded breast tissue blocks were sectioned, deparaffinized and immunostained $22,39,63$. Immunohistochemical staining of the sections were performed using standard procedures using the following primary antibodies: $\alpha$ CD4 antibody (abcam\# ab133616; dilution 1:200), a-CD36 antibody (Abcam \# ab80080, clone MF3, dilution: 1:200), $\alpha-$ T-bet antibody (Abcam \# ab91109, clone 4B10, dilution: 1:200). To enable fluorescence detection, sections were incubated with appropriate Alexa Fluor ${ }^{\circledR} 488$ (green, Molecular probes), or Alexa Fluor® 564 (red, Molecular probes) conjugated secondary antibodies. The sections were counterstained with DAPI (Sigma). For immunocytochemistry, cells were fixed with IC fixation buffer (eBioscience), blocked with 10 percent normal goat serum (Vector Laboratories), incubated with primary and secondary antibodies and counterstained with DAPI. Mosaic images were collected using a Zeiss Axiovert $200 \mathrm{M}$, inverted fluorescence microscopy or confocal microscopy (LSM880). Image analysis was performed using Zen (Zeiss) software to quantitate fluorescence intensity (fluorescent pixels).

Lipid extraction and 10-HOME quantification using LCMS. LC-MS/MS targeted analysis from capsule and breast adipose tissue was performed. Samples were weighed and transferred to 2 $\mathrm{ml}$ vials with $1.4 \mathrm{~mm}$ ceramic beads and $1 \mathrm{ml}$ of water with $0.1 \%$ formic acid. The standard solution was prepared by aliquoting $1 \mu \mathrm{l}$ of each stock solution into a new tube drying the original solvent and solubilizing in $1 \mathrm{ml}$ of $100 \%$ ethanol to obtain a final concentration of $1 \mathrm{ng} / \mathrm{ml}$ each. Samples were homogenized using Precellys24 tissue homogenizer (Bertin Technologies, Rockville, MD). The total volume of the homogenate was extracted with ethyl acetate in a 1:1 volume ratio. Samples were vortexed for 1 minute and centrifuged at $14.000 \mathrm{rpm}$ for 10 minutes. The organic phase was collected and transferred to a new vial to be evaporated and stored at $-80^{\circ} \mathrm{C}$ until analysis. The dried lipid extracts were reconstituted with $50 \mu$ of methanol/water at 1:1 volume 
medRxiv preprint doi: https://doi.org/10.1101/2020.11.18.20233510; this version posted November 20, 2020. The copyright holder for this preprint (which was not certified by peer review) is the author/funder, who has granted medRxiv a license to display the preprint in perpetuity.

It is made available under a CC-BY-NC-ND 4.0 International license .

334

335

336

337

338

339

340

341

342

343

344

345

346

347

348

349

350

351

352

353

354

355

356

357

358

ratio and submitted for targeted quantification by liquid chromatography tandem MS (LC/MS/MS).

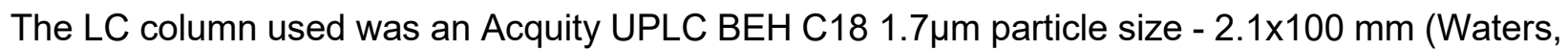
Milford, MA). The binary pump flow rate was set at $0.3 \mathrm{~mL} / \mathrm{min}$ in an Agilent UPLC (G7120A) using water and $0.1 \%$ formic acid as mobile phase $\mathrm{A}$ and acetonitrile and $0.1 \%$ formic acid as mobile phase B. The LC column was pre-equilibrated with $80 \%$ A for 1 min. The binary pump was set in a linear gradient to $100 \% \mathrm{~B}$ in $8 \mathrm{~min}$ and held for $2.50 \mathrm{~min}$. It was then returned to $80 \% \mathrm{~A}$ and reequilibrated for $4 \mathrm{~min}$. Ten $\mu \mathrm{L}$ of the reconstituted sample was delivered to the column through a multisampler (G7167B) into a QQQ6470A triple quadrupole mass spectrometer (Agilent Technologies, San Jose, CA) equipped with ESI Jet Stream ion source. In the mass spectrometer the capillary voltage was $3500 \mathrm{~V}$ on the negative ion mode, the gas temperature was $325^{\circ} \mathrm{C}$, gas flow was set at $81 / \mathrm{min}$, the sheath gas heater at $250^{\circ} \mathrm{C}$ and the sheath gas flow at $7 \mathrm{l} / \mathrm{min}$. The fragmentation voltage was 100 and the cell accelerator voltage was $4 \mathrm{~V}$. The MRMs (parentfragment) for the acquisition included were 297.5->155.4 for 10-HOME and for the internal standard it was 302.4->155.4. Concentrations in $\mathrm{ng} / \mathrm{mg}$ of tissue were obtained by normalizing by the dried weight of the sample homogenized and by the concentration of the deuterated internal standard. To quantify 10-HOME, calibration curves were done with 7 serial dilutions of the stock solution starting at $10 \mathrm{ng}$ as the highest concentration. Data processing was carried out by using Mass Hunter (B.06.00) using software Quant and Qual.

Flow cytometry analyses. The fluorescence and light-scattering properties (forward scatter and side scatter) of the cells were determined by using BD Accuri C6. Signals from cells labeled with conjugated fluorophores were detected. The following antibodies were used for different flow cytometry analysis. PE anti-human CD183 (CXCR3) (clone G025H7, Biolegend \# 353705, 2

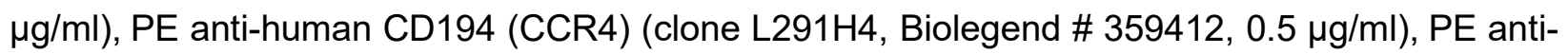
human CD196 (CCR6) (clone G034E3, Biolegend \# 353410, $0.5 \mu \mathrm{g} / \mathrm{ml}$ ), FITC anti-human CD4 (clone A161A1, Biolegend \# 357406 , 0.5 g/ml), APC anti-human CD194 (CCR4) (clone L291H4, 
medRxiv preprint doi: https://doi.org/10.1101/2020.11.18.20233510; this version posted November 20, 2020. The copyright holder for this preprint (which was not certified by peer review) is the author/funder, who has granted medRxiv a license to display the preprint in perpetuity.

It is made available under a CC-BY-NC-ND 4.0 International license .

Biolegend \# 359407, 0.5 g/ml), Alexa Fluor® 700 anti-human CD196 (CCR6) (clone G034E3, Biolegend \# 353433, $0.5 \mu \mathrm{g} / \mathrm{ml}$ ), PE anti-human CD36 (clone 5-271, Biolegend \# 336205, 1 $\mu \mathrm{g} / \mathrm{ml}$ ), FITC anti-mouse CD4 (clone GK1.5, Biolegend \# 100406, $0.5 \mu \mathrm{g} / \mathrm{ml}$ ), APC anti-mouse CD36 (clone HM36, Biolegend \# 102612, 0.5 g/ml), PE anti-mouse CD183 CD36 (clone CXCR3-

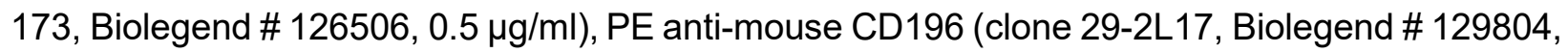
$0.5 \mu \mathrm{g} / \mathrm{ml}$ ), APC anti-mouse CD194 (clone 2G12, Biolegend \# 131211, $0.5 \mu \mathrm{g} / \mathrm{ml}$ ), PE anti-mouse FOXP3 (clone MF14, Biolegend \# 126403, $0.5 \mu \mathrm{g} / \mathrm{ml}$ ), PE anti-T-bet Antibody (clone 4B10, Biolegend \# 644809, $0.5 \mu \mathrm{g} / \mathrm{ml})$. For intracellular markers, TBET and GATA3 permeabilization was performed through True-nuclear transcription factor buffer set (Biolegend \# 424401). Auto compensation was performed using samples stained with single flurophores. Gates were set manually. BD Diva (BD Biosciences), and FlowJo softwares were used for analyses ${ }^{63}$. Logarithmic scale was used to measure cell fluorescence. Appropriate lgG control fluorescence compensation was applied to avoid false positive signals.

ELISA. Cell-free supernatants were collected and stored at $-80^{\circ} \mathrm{C}$. ELISAs for IFN-y, IL4 and IL10 were performed using DuoSet kits (R\&D Systems) as per manufacturer's protocol.

10-HOME administration in mice. At approximately 9 to 10 weeks of age, female mice were anesthetized with isoflurane, and five injections of 10-HOME (15 mg/kg body weight) every alternate day was made with a $27 \mathrm{G}$ needle to the abdominal mammary fat pad of mice. Post-two weeks of the dose the mice were euthanized. Blood, mammary fat pad and spleen were harvested for subsequent analyses.

Quantitative RT PCR. Breast tissue was pulverized using tissue pulverizer (6770 Freezer/Mill) and total RNA was extracted using miRVana (Thermo Fisher Scientific). cDNA was made using SuperScript ${ }^{\mathrm{TM}}$ III First-Strand Synthesis System (Invitrogen) or SuperScript ${ }^{\mathrm{TM}}$ VILO ${ }^{\mathrm{TM}}$ cDNA Synthesis Kit (Invitrogen). Quantitative or real-time PCR (Sybr Green) approach was used for 
medRxiv preprint doi: https://doi.org/10.1101/2020.11.18.20233510; this version posted November $20,2020$. The copyright holder for this preprint (which was not certified by peer review) is the author/funder, who has granted medRxiv a license to display the preprint in perpetuity.

It is made available under a CC-BY-NC-ND 4.0 International license .

383

mRNA quantification ${ }^{63-68}$. Primer sequences used in this study provided in (Supplementary Table 3).

\section{Quantification and statistical analysis}

The data analysis was performed using student's t-test (two-tailed) to determine significant differences. Mean, standard deviation and student paired $t$-test analysis was done using in-built function in Microsoft Excel 2010. Data are presented as mean \pm SEM (in vivo) or \pm SD (in vitro) as reported in figure legends. Comparisons among multiple groups were tested using ANOVA inbuilt function in GraphPad Prism 8.4.2. $\mathrm{p}<0.05$ was considered statistically significant.

\section{ACKNOWLEDGEMENTS}

This work was supported by Aesthetic Surgery Education and Research Foundation (ASERF) grant to MS, Department of Defense PR200435, and American Association of Plastic Surgeons grants to $\mathrm{AHH}$, the US National Institutes of Health grants NIH NR015676, U01DK119099 to GG and CKS; NIH R01GM108014, R01NS042617, R01DK125835 to CKS. The authors acknowledge Core Services for SEM at INDI Core, Indiana University Purdue University Indianapolis. We thank Metabolite Profiling Facility, Purdue University, West Lafayette. We thank Dr. Lava Timsina, Indiana University School of Medicine for his help with the statistics. We thank Dr. Allen Epstein, Keck School of Medicine, University of Southern California for his kind donation of the breast implant-associated anaplastic large cell lymphoma (BIA-ALCL), T cell line TLBR1.

\section{AUTHOR CONTRIBUTIONS}

MS, IK, and AHH conceived and designed the work. IK, REM, CKP, BWV, CRN, LS, KS, ML, JVD participated in the data acquisition. MS, REM, IK, CKP, AHH and MEK wrote the manuscript. MS, REM, CKS, GMG, MEK, BWV reviewed the manuscript. 


\section{DECLARATION OF INTERESTS}

407 The authors declare no competing interests

408 REFERENCES

409 1. Safety of Silicone Breast Implants. In: S. Bondurant, V. Ernster and R. Herdman, eds.

410 Institute of Medicine Washington (DC): The National Academies Press;

411 1999(https://doi.org/10.17226/9602).

$412 \quad 2 . \quad$ FDA Update on the Safety of Silicone Gel-Filled Breast Implants.

413 2011; https://www.fda.gov/media/80685/download.

4143.2019 Plastic Surgery Statistics. 2019; 2 https://www.plasticsurgery.org/news/plastic-

415 surgery-statistics.

416 4. Fryzek JP, Signorello LB, Hakelius L, Feltelius N, Ringberg A, Blot WJ, McLaughlin JK

417 and Nyren O. Self-reported symptoms among women after cosmetic breast implant and breast

418 reduction surgery. Plast Reconstr Surg. 2001;107:206-13.

419 5. Maijers MC, de Blok CJ, Niessen FB, van der Veldt AA, Ritt MJ, Winters HA, Kramer MH

420 and Nanayakkara PW. Women with silicone breast implants and unexplained systemic

421 symptoms: a descriptive cohort study. Neth J Med. 2013;71:534-40.

$422 \quad 6 . \quad$ ASAPS. Breast Implant Illness - Frequently Asked Questions/Talking Points.

423 https://wwwsurgeryorg/sites/default/files/Breast/mplant/lIness 8-21-2019 FINALpdf. 2019.

424 7. Balk EM, Earley A, Avendano EA and Raman G. Long-Term Health Outcomes in

425 Women With Silicone Gel Breast Implants: A Systematic Review. Ann Intern Med.

$426 \quad 2016 ; 164: 164-75$.

427 8. Coroneos CJ, Selber JC, Offodile AC, 2nd, Butler CE and Clemens MW. US FDA Breast

428 Implant Postapproval Studies: Long-term Outcomes in 99,993 Patients. Ann Surg. 2019;269:30-

42936. 
medRxiv preprint doi: https://doi.org/10.1101/2020.11.18.20233510; this version posted November 20, 2020. The copyright holder for this

preprint (which was not certified by peer review) is the author/funder, who has granted medRxiv a license to display the preprint in perpetuity.

It is made available under a CC-BY-NC-ND 4.0 International license .

430 9. Khoo T, Proudman S and Limaye V. Silicone breast implants and depression,

431 fibromyalgia and chronic fatigue syndrome in a rheumatology clinic population. Clin Rheumatol.

$432 \quad 2019 ; 38: 1271-1276$.

433 10. Lee IM, Cook NR, Shadick NA, Pereira E and Buring JE. Prospective cohort study of

434 breast implants and the risk of connective-tissue diseases. Int J Epidemiol. 2011;40:230-8.

435 11. Singh N, Picha GJ, Hardas B, Schumacher A and Murphy DK. Five-Year Safety Data for

436 More than 55,000 Subjects following Breast Implantation: Comparison of Rare Adverse Event

437 Rates with Silicone Implants versus National Norms and Saline Implants. Plast Reconstr Surg.

$438 \quad 2017 ; 140: 666-679$.

439 12. Watad A, Rosenberg V, Tiosano S, Cohen Tervaert JW, Yavne Y, Shoenfeld Y, Shalev

$440 \mathrm{~V}$, Chodick $\mathrm{G}$ and Amital $\mathrm{H}$. Silicone breast implants and the risk of autoimmune/rheumatic

441 disorders: a real-world analysis. Int J Epidemiol. 2018;47:1846-1854.

442 13. de Boer M, Colaris M, van der Hulst R and Cohen Tervaert JW. Is explantation of

443 silicone breast implants useful in patients with complaints? Immunol Res. 2017;65:25-36.

444 14. Peters W, Smith D, Fornasier V, Lugowski S and Ibanez D. An outcome analysis of 100

445 women after explantation of silicone gel breast implants. Ann Plast Surg. 1997;39:9-19.

446 15. Tanne JH. FDA approves silicone breast implants 14 years after their withdrawal. BMJ.

$447 \quad 2006 ; 333: 1139$.

448 16. Alijotas-Reig J, Esteve-Valverde E, Gil-Aliberas N and Garcia-Gimenez V.

449 Autoimmune/inflammatory syndrome induced by adjuvants-ASIA-related to biomaterials:

450 analysis of 45 cases and comprehensive review of the literature. Immunol Res. 2018;66:120-

451140.

452 17. Greenland S and Finkle WD. A case-control study of prosthetic implants and selected

453 chronic diseases in Medicare claims data. Ann Epidemiol. 1998;8:319-26. 
454 18. Laing TJ, Schottenfeld D, Lacey JV, Jr., Gillespie BW, Garabrant DH, Cooper BC,

455 Heeringa SG, Alcser KH and Mayes MD. Potential risk factors for undifferentiated connective

456 tissue disease among women: implanted medical devices. Am J Epidemiol. 2001;154:610-7.

457 19. Mellemkjaer L, Friis S, McLaughlin JK, Thomsen BL, Kjoller K, Hogsted C, Winther JF,

458 Blot WJ and Olsen JH. Connective tissue disease after hip and knee implant surgery. Scand J

459 Rheumatol. 2001;30:82-6.

460 20. Signorello LB, Ye W, Fryzek JP, Blot WJ, Lipworth L, McLaughlin JK and Nyren O. A

461 nationwide followup study of autoimmune and connective tissue disease among hip and knee

462 implant patients. J Long Term Eff Med Implants. 2002;12:255-62.

463 21. Vyas KS and Wong LK. Detection of Biofilm in Wounds as an Early Indicator for Risk for

464 Tissue Infection and Wound Chronicity. Ann Plast Surg. 2016;76:127-31.

465 22. Roy S, Elgharably H, Sinha M, Ganesh K, Chaney S, Mann E, Miller C, Khanna S, 466 Bergdall VK, Powell HM, Cook CH, Gordillo GM, Wozniak DJ and Sen CK. Mixed-species

467 biofilm compromises wound healing by disrupting epidermal barrier function. $J$ Pathol.

$468 \quad 2014 ; 233: 331-343$.

469 23. Rhoads DD, Cox SB, Rees EJ, Sun Y and Wolcott RD. Clinical identification of bacteria

470 in human chronic wound infections: culturing vs. 16S ribosomal DNA sequencing. BMC Infect

$471 \quad$ Dis. 2012;12:321.

472 24. Martinez E and Campos-Gomez J. Oxylipins produced by Pseudomonas aeruginosa

473 promote biofilm formation and virulence. Nat Commun. 2016;7:13823.

474 25. Levan SR, Stamnes KA, Lin DL, Fujimura KE, Ownby DR, Zoratti EM, Boushey HA,

475 Johnson CC and Lynch SV. Neonatal gut-microbiome-derived 12,13 DiHOME impedes

476 tolerance and promotes childhood atopy and asthma. bioRxiv. 2018:311704.

477 26. Kanhere A, Hertweck A, Bhatia U, Gokmen MR, Perucha E, Jackson I, Lord GM and

478 Jenner RG. T-bet and GATA3 orchestrate Th1 and Th2 differentiation through lineage-specific

479 targeting of distal regulatory elements. Nat Commun. 2012;3:1268. 
medRxiv preprint doi: https://doi.org/10.1101/2020.11.18.20233510; this version posted November 20, 2020. The copyright holder for this preprint (which was not certified by peer review) is the author/funder, who has granted medRxiv a license to display the preprint in perpetuity.

It is made available under a CC-BY-NC-ND 4.0 International license .

480 27. Skapenko A, Leipe J, Lipsky PE and Schulze-Koops H. The role of the T cell in

481 autoimmune inflammation. Arthritis Research \& Therapy. 2005;7:S4.

482 28. Zhang X, Fitzsimmons RL, Cleland LG, Ey PL, Zannettino AC, Farmer EA, Sincock P 483 and Mayrhofer G. CD36/fatty acid translocase in rats: distribution, isolation from hepatocytes, 484 and comparison with the scavenger receptor SR-B1. Lab Invest. 2003;83:317-32.

485 29. Perera LP, Zhang M, Nakagawa M, Petrus MN, Maeda M, Kadin ME, Waldmann TA and 486 Perera PY. Chimeric antigen receptor modified T cells that target chemokine receptor CCR4 as 487 a therapeutic modality for T-cell malignancies. Am J Hematol. 2017;92:892-901.

488 30. Oishi N, Hundal T, Phillips JL, Dasari S, Hu G, Viswanatha DS, He R, Mai M, Jacobs 489 HK, Ahmed NH, Syrbu SI, Salama Y, Chapman JR, Vega F, Sidhu J, Bennani NN, Epstein AL, 490 Medeiros LJ, Clemens MW, Miranda RN and Feldman AL. Molecular profiling reveals a hypoxia 491 signature in breast implant-associated anaplastic large cell lymphoma. Haematologica. 2020.

492 31. Kostakioti M, Hadjifrangiskou M and Hultgren SJ. Bacterial biofilms: development, 493 dispersal, and therapeutic strategies in the dawn of the postantibiotic era. Cold Spring Harb $494 \quad$ Perspect Med. 2013;3:a010306.

495 32. Parsonnet J. Bacterial infection as a cause of cancer. Environ Health Perspect. $496 \quad$ 1995;103 Suppl 8:263-8.

497 33. Mousa JJ, Yang Y, Tomkovich S, Shima A, Newsome RC, Tripathi P, Oswald E, Bruner 498 SD and Jobin C. MATE transport of the E. coli-derived genotoxin colibactin. Nat Microbiol. $499 \quad 2016 ; 1: 15009$.

500 34. Tomkovich S, Yang Y, Winglee K, Gauthier J, Muhlbauer M, Sun X, Mohamadzadeh M, 501 Liu X, Martin P, Wang GP, Oswald E, Fodor AA and Jobin C. Locoregional Effects of Microbiota 502 in a Preclinical Model of Colon Carcinogenesis. Cancer Res. 2017;77:2620-2632.

503 35. Cappelli G, Tetta C and Canaud B. Is biofilm a cause of silent chronic inflammation in 504 haemodialysis patients? A fascinating working hypothesis. Nephrol Dial Transplant. $505 \quad 2005 ; 20: 266-70$. 
medRxiv preprint doi: https://doi.org/10.1101/2020.11.18.20233510; this version posted November 20, 2020. The copyright holder for this preprint (which was not certified by peer review) is the author/funder, who has granted medRxiv a license to display the preprint in perpetuity.

It is made available under a CC-BY-NC-ND 4.0 International license .

506 36. Zhao G, Usui ML, Lippman SI, James GA, Stewart PS, Fleckman P and Olerud JE.

507 Biofilms and Inflammation in Chronic Wounds. Adv Wound Care (New Rochelle). 2013;2:389-

508399.

509 37. Hu H, Johani K, Almatroudi A, Vickery K, Van Natta B, Kadin ME, Brody G, Clemens M,

510 Cheah CY, Lade S, Joshi PA, Prince HM and Deva AK. Bacterial Biofilm Infection Detected in

511 Breast Implant-Associated Anaplastic Large-Cell Lymphoma. Plast Reconstr Surg.

$512 \quad 2016 ; 137: 1659-69$.

513 38. Barki KG, Das A, Dixith S, Ghatak PD, Mathew-Steiner S, Schwab E, Khanna S,

514 Wozniak DJ, Roy S and Sen CK. Electric Field Based Dressing Disrupts Mixed-Species

515 Bacterial Biofilm Infection and Restores Functional Wound Healing. Ann Surg. 2019;269:756-

516766.

517 39. Roy S, Santra S, Das A, Dixith S, Sinha M, Ghatak S, Ghosh N, Banerjee P, Khanna S,

518 Mathew-Steiner S, Ghatak PD, Blackstone BN, Powell HM, Bergdall VK, Wozniak DJ and Sen

519 CK. Staphylococcus aureus Biofilm Infection Compromises Wound Healing by Causing

520 Deficiencies in Granulation Tissue Collagen. Ann Surg. 2020;271:1174-1185.

521 40. James GA, Boegli L, Hancock J, Bowersock L, Parker A and Kinney BM. Bacterial

522 Adhesion and Biofilm Formation on Textured Breast Implant Shell Materials. Aesthetic Plast

523 Surg. 2019;43:490-497.

524 41. Urbaniak C, Cummins J, Brackstone M, Macklaim JM, Gloor GB, Baban CK, Scott L,

525 O'Hanlon DM, Burton JP, Francis KP, Tangney M and Reid G. Microbiota of human breast

526 tissue. Appl Environ Microbiol. 2014;80:3007-14.

527 42. Brandwein M, Steinberg D and Meshner S. Microbial biofilms and the human skin

528 microbiome. NPJ Biofilms Microbiomes. 2016;2:3.

529 43. Cohen JB, Carroll C, Tenenbaum MM and Myckatyn TM. Breast Implant-Associated

530 Infections: The Role of the National Surgical Quality Improvement Program and the Local

531 Microbiome. Plast Reconstr Surg. 2015;136:921-9. 
44. Walker JN, Poppler LH, Pinkner CL, Hultgren SJ and Myckatyn TM. Establishment and Characterization of Bacterial Infection of Breast Implants in a Murine Model. Aesthet Surg J. 2020;40:516-528.

45. Song JH, Kim YS, Jung BK, Lee DW, Song SY, Roh TS and Lew DH. Salvage of Infected Breast Implants. Arch Plast Surg. 2017;44:516-522.

46. Brindle CT, Porter S, Bijlani K, Arumugam S, Matias R, Najafi R and Fisher J. Preliminary Results of the Use of a Stabilized Hypochlorous Acid Solution in the Management of Ralstonia Pickettii Biofilm on Silicone Breast Implants. Aesthet Surg J. 2018;38:S52-S61.

47. Azeredo J, Azevedo NF, Briandet R, Cerca N, Coenye T, Costa AR, Desvaux M, Di Bonaventura G, Hebraud M, Jaglic Z, Kacaniova M, Knochel S, Lourenco A, Mergulhao F, Meyer RL, Nychas G, Simoes M, Tresse O and Sternberg C. Critical review on biofilm methods. Crit Rev Microbiol. 2017;43:313-351.

48. Swearingen MC, DiBartola AC, Dusane D, Granger J and Stoodley P. 16S rRNA analysis provides evidence of biofilms on all components of three infected periprosthetic knees including permanent braided suture. Pathog Dis. 2016;74.

49. Lee M, Ponraja G, McLeod K and Chong S. Breast Implant Illness: A Biofilm Hypothesis. Plast Reconstr Surg Glob Open. 2020;8:e2755.

50. Chajes V, Niyongabo T, Lanson M, Fignon A, Couet C and Bougnoux P. Fatty-acid composition of breast and iliac adipose tissue in breast-cancer patients. Int $J$ Cancer. 1992;50:405-8.

51. Zhu ZR, Agren J, Mannisto S, Pietinen P, Eskelinen M, Syrjanen K and Uusitupa M. Fatty acid composition of breast adipose tissue in breast cancer patients and in patients with benign breast disease. Nutr Cancer. 1995;24:151-60.

52. Kotsougiani D, Pioch M, Prior B, Heppert V, Hansch GM and Wagner C. Activation of T Lymphocytes in Response to Persistent Bacterial Infection: Induction of CD11b and of Toll-Like Receptors on T Cells. Int J Inflam. 2010;2010:526740. 
medRxiv preprint doi: https://doi.org/10.1101/2020.11.18.20233510; this version posted November 20, 2020. The copyright holder for this preprint (which was not certified by peer review) is the author/funder, who has granted medRxiv a license to display the preprint in perpetuity.

It is made available under a CC-BY-NC-ND 4.0 International license.

558 53. Gonzalez JF, Hahn MM and Gunn JS. Chronic biofilm-based infections: skewing of the

559 immune response. Pathog Dis. 2018;76.

560 54. Steinman L. A few autoreactive cells in an autoimmune infiltrate control a vast population

561 of nonspecific cells: a tale of smart bombs and the infantry. Proc Natl Acad Sci U S A.

562 1996;93:2253-6.

563 55. Nicholson LB and Kuchroo VK. Manipulation of the Th1/Th2 balance in autoimmune

564 disease. Curr Opin Immunol. 1996;8:837-42.

565 56. Liblau RS, Singer SM and McDevitt HO. Th1 and Th2 CD4+ T cells in the pathogenesis

566 of organ-specific autoimmune diseases. Immunol Today. 1995;16:34-8.

567 57. Raphael I, Nalawade S, Eagar TN and Forsthuber TG. T cell subsets and their signature

568 cytokines in autoimmune and inflammatory diseases. Cytokine. 2015;74:5-17.

569 58. Osthues T and Sisignano M. Oxidized Lipids in Persistent Pain States. Front Pharmacol. $570 \quad 2019 ; 10: 1147$.

571 59. Tabarkiewicz J, Pogoda K, Karczmarczyk A, Pozarowski P and Giannopoulos K. The

572 Role of IL-17 and Th17 Lymphocytes in Autoimmune Diseases. Arch Immunol Ther Exp

573 (Warsz). 2015;63:435-49.

574 60. Deng B, Ghatak S, Sarkar S, Singh K, Das Ghatak P, Mathew-Steiner SS, Roy S,

575 Khanna S, Wozniak DJ, McComb DW and Sen CK. Novel Bacterial Diversity and Fragmented

576 eDNA Identified in Hyperbiofilm-Forming Pseudomonas aeruginosa Rugose Small Colony

577 Variant. iScience. 2020;23:100827.

578 61. Shen W, Falahati R, Stark R, Leitenberg D and Ladisch S. Modulation of CD4 Th cell

579 differentiation by ganglioside GD1a in vitro. J Immunol. 2005;175:4927-34.

580 62. Ganusov VV, Milutinovic D and De Boer RJ. IL-2 regulates expansion of CD4+ T cell

581 populations by affecting cell death: insights from modeling CFSE data. J Immunol.

$582 \quad 2007 ; 179: 950-7$. 
63. Sinha M, Sen CK, Singh K, Das A, Ghatak S, Rhea B, Blackstone B, Powell HM,

584 Khanna S and Roy S. Direct conversion of injury-site myeloid cells to fibroblast-like cells of

585 granulation tissue. Nat Commun. 2018;9:936.

586 64. Das A, Ganesh K, Khanna S, Sen CK and Roy S. Engulfment of apoptotic cells by

587 macrophages: a role of microRNA-21 in the resolution of wound inflammation. J Immunol.

$588 \quad 2014 ; 192: 1120-9$.

589 65. Das A, Ghatak S, Sinha M, Chaffee S, Ahmed NS, Parinandi NL, Wohleb ES, Sheridan

590 JF, Sen CK and Roy S. Correction of MFG-E8 Resolves Inflammation and Promotes Cutaneous

591 Wound Healing in Diabetes. J Immunol. 2016;196:5089-100.

592 66. Ganesh K, Das A, Dickerson R, Khanna S, Parinandi NL, Gordillo GM, Sen CK and Roy

593 S. Prostaglandin E(2) induces oncostatin M expression in human chronic wound macrophages

594 through Axl receptor tyrosine kinase pathway. J Immunol. 2012;189:2563-73.

595 67. Khanna S, Biswas S, Shang Y, Collard E, Azad A, Kauh C, Bhasker V, Gordillo GM, Sen

596 CK and Roy S. Macrophage dysfunction impairs resolution of inflammation in the wounds of

597 diabetic mice. PLoS One. 2010;5:e9539.

598 68. Das A, Datta S, Roche E, Chaffee S, Jose E, Shi L, Grover K, Khanna S, Sen CK and

599 Roy S. Novel mechanisms of Collagenase Santyl Ointment (CSO) in wound macrophage

600 polarization and resolution of wound inflammation. Sci Rep. 2018;8:1696.

601

602

603

604 
medRxiv preprint doi: https://doi.org/10.1101/2020.11.18.20233510; this version posted November 20, 2020. The copyright holder for this preprint (which was not certified by peer review) is the author/funder, who has granted medRxiv a license to display the preprint in perpetuity.

It is made available under a CC-BY-NC-ND 4.0 International license .

\section{Figure 1. Bacterial Biofilm in Implant-Associated with BII}

(A) Schematic presentation of the bacterial biofilm association with breast implant illness (BII)

(B) Breast implant isolated from a subject

(C) Capsule associated with breast implant of the subject shown in (B)

(D) Increased abundance of bacterial biofilm from the implant-associated capsule of Bll compared to non Bll subjects as determined through scanning electron microscopy. Zoomed insets of region of interest (ROI) dotted yellow square shown. $n=10$ non-BII subjects, $n=25$ Bll subjects.

(E-F) E, Increased abundance of bacterial biofilm as measured through wheat germ agglutinin (WGA) assay in the capsules of Bll subjects compared to the non-BII capsules. F, quantification of biofilm aggregates using WGA staining. Data presented as mean \pm SEM, $n=7$ non-BII, $n=7$ BII

(G-I) 16S rRNA NGS based bacterial typing from the breast tissues of G, normal; $\mathbf{H}$, non-BII and I, BII subjects. Top five bacterial species in each group represented. Absolute values of subject samples associated with a bacterial species is provided in parenthesis $n=8$ (normal), $n=14$ (non-BII), $n=46$ (BII)

(J) Increased abundance of biofilm forming Staphylococcus epidermidis in implant-associated breast tissues of Bll subjects. Percentage of Patients with Cutibacterium acnes and Staphylococcus epidermidis provided above the individual bars. $n=8$ (normal), $n=14$ (non-BII), $n=46$ (BII) 
medRxiv preprint doi: https://doi.org/10.1101/2020.11.18.20233510; this version posted November 20, 2020. The copyright holder for this

A preprint (which was not certified by peeBeview is the auther/funder, who has granted medRxiv a It is made avarlabble under a CC-BY-NC-ND 4.0 International licentse

oleic acid

oxidation by biofilm enzymes

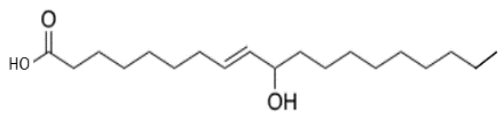

10-HOME

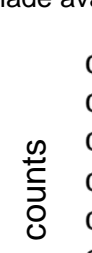

10-HOME d5

0.9

0.8

0.7

0.6

0.5

0.4

0.3

0.2

0.1

10-HOME (target)

0

$$
7
$$

internal std

$$
\text { 옹 }
$$

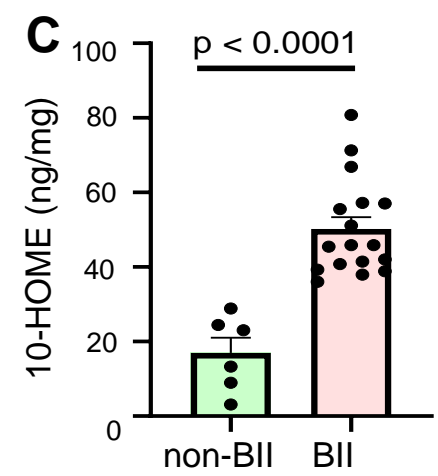

E

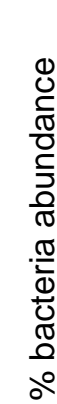

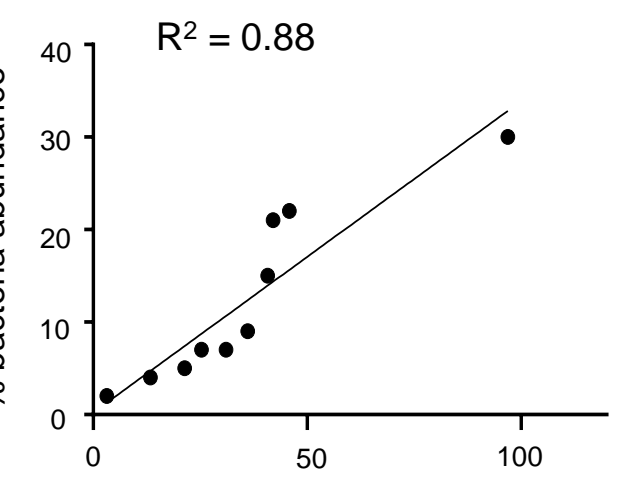

10-HOME (ng/mg)

D

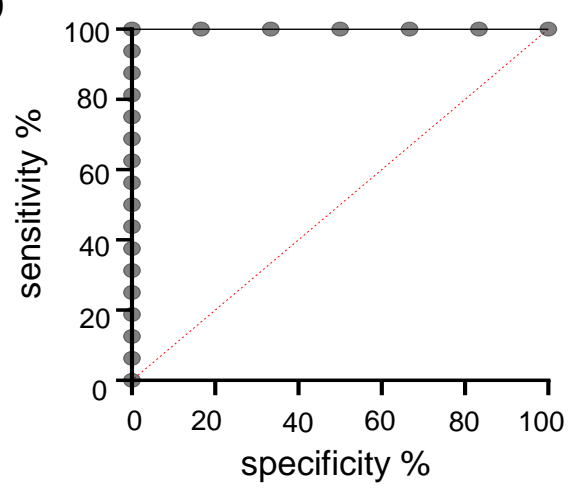

F

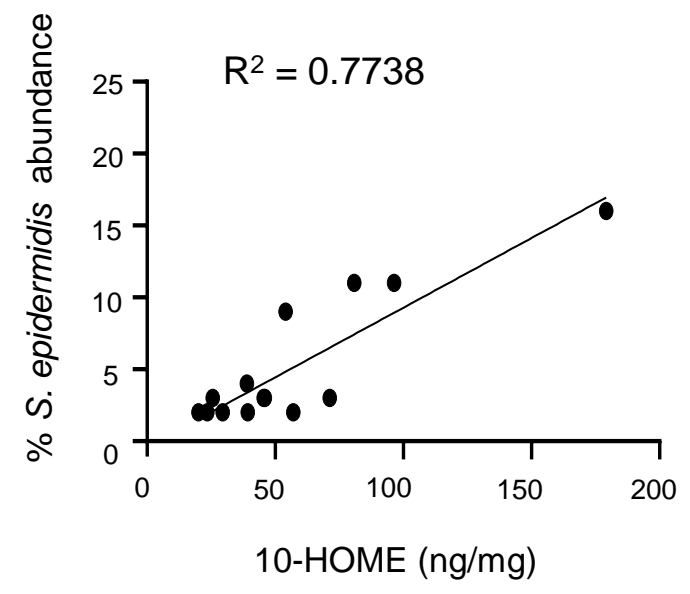

10-HOME d5 internal std

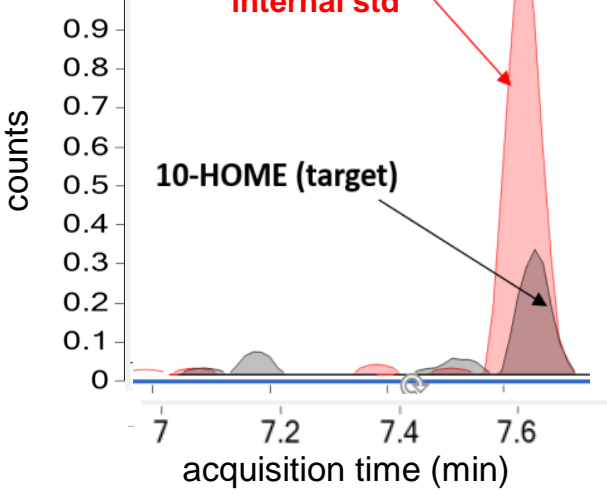

G

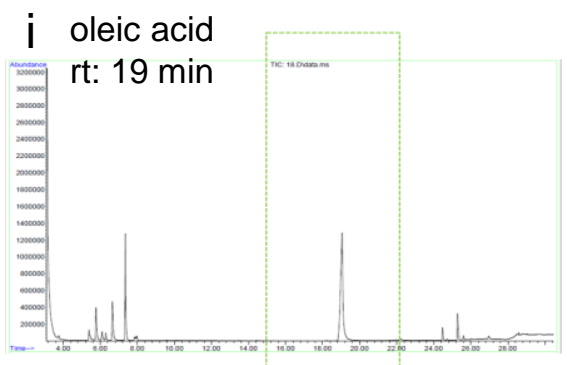

iii S. epidermidis + Glucose

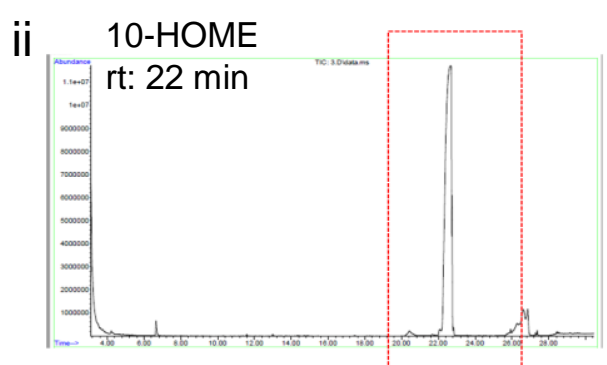

iv S. epidermidis + oleic acid

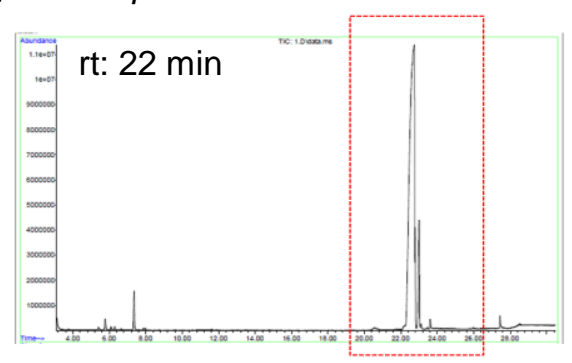

V

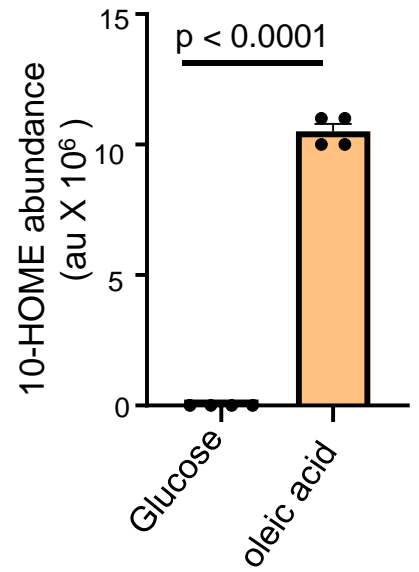


medRxiv preprint doi: https://doi.org/10.1101/2020.11.18.20233510; this version posted November 20, 2020. The copyright holder for this preprint (which was not certified by peer review) is the author/funder, who has granted medRxiv a license to display the preprint in perpetuity.

It is made available under a CC-BY-NC-ND 4.0 International license .

\section{Figure 2 .Increased Abundance of Biofilm Derived 10-HOME in BII Subjects}

(A) Schematic of formation of 10-HOME from oleic acid

(B-D) Increased abundance of 10-HOME in implant associated tissue of Bll subjects. B. Chromatograms of 10-HOME from non-BII and BII using LC-MS/MS targeted analyses. C. Data presented as mean \pm SEM, $n=6$ (non-BII), $n=17$ (BII). D. Receiver operating characteristic (ROC) curve analysis to determine specificity and sensitivity of 10-HOME detection.

(E) Increased abundance of bacteria associated with 10-HOME detected from the implant associated tissue of Bll subjects.

(F) Increased abundance of Staphylococcus epidermidis associated with 10-HOME detected from the implant associated tissue of Bll subjects.

(G) Synthesis of 10-HOME by $S$. epidermidis in vitro upon using oleic acid as carbon source. Gas chromatography- mass spectrometry analyses for detection of 10-HOME. i- oleic acid standard, ii10-HOME standard, iii- S.epidermidis with glucose as carbon source, iv- S.epidermidis with Oleic acid as carbon source, $\mathbf{v}$ - quantification of $10-\mathrm{HOME}$ abundance. $n=4$ 
medRxiv preprint doi: https://doi.org/10.1101/2020.11.18.20233510; this version posted November 20, 2020. The copyright holder for this preprint (which was not certified by peer review) is the author/funder, who has granted medRxiv a license to display the preprint in perpetuity.

It is made available under a CC-BY-NC-ND 4.0 International license .

\section{Figure 3. Abundance of CD4+ Th1 Cells in Implant Associated Tissue of Bll Subjects}

(A) Increased expression of T-BET (transcription factor for Th1 subtype) in breast tissue associated with Bll subjects compared to non-BIl breast tissue. Breast tissue immuno-stained with anti-CD4 (red) antibody, anti-T-BET (green) and DAPI (blue). Intensity of TBET for the two groups, colocalization of CD4 and T-BET depicted increased abundance of CD4+ TBET+ cells in the breast tissues of BII subjects. Data presented as mean \pm SEM, $(n=7)$. Scale bar $=20 \mu \mathrm{m}$

(B) Increased expression of CD36 (fatty acyl translocase) in breast tissue associated with Bll subjects compared to non-BII breast tissue. Breast tissue immuno-stained with anti-CD4 (red) antibody, antiCD36 (green) and DAPI (blue). Intensity of CD36 for the two groups, colocalization of CD4 and CD36 depicted increased abundance of $\mathrm{CD} 4^{+} \mathrm{CD} 36^{+}$cells in the breast tissues of Bll subjects. Data presented as mean \pm SEM, $(n=7)$. Scale bar $=20 \mu \mathrm{m}$

(C) Elevated Th1 subtype in the peripheral blood of Bll subjects. Flow cytometry analyses of peripheral blood of subjects stained with anti-CD4 (FITC) and anti-CD183 (PE). Representative flow plots. (i) non-BII (ii) BII (iii) histogram with isotype control for CD183 (iv) \% of CD4+ CD183+ T cells. Data presented as mean \pm SEM, $(n=5-11)$. 
medRxiv preprint doi: https://doi.org/10.1101/2020.11.18.20233510; this version posted November 20, 2020. The copyright holder for this preprint (which was not certified by peer review) is the author/funder, who has granted medRxiv a license to display the preprint in perpetuity.

It is made available under a CC-BY-NC-ND 4.0 International license .

\section{Figure 4. Oxylipin 10-HOME Polarizes Naïve CD4+ T Cells to Th1 Subtype in vitro}

(A) Increased expression of CD36 in naïve CD4+ $\mathrm{T}$ cells treated with $100 \mu \mathrm{m}$ of 10 -HOME compared to vehicle post-48h. T cells were immuno-stained with anti-CD4 (red) antibody, anti- CD36 (green) and DAPI (blue). Intensity of CD36 quantified for the two groups. Colocalization of CD4 and TBET depicted increased abundance of $\mathrm{CD} 4{ }^{+} \mathrm{CD} 36{ }^{+}$cells in the breast tissues of Bll subjects. Data presented as mean $\pm S D,(n=6)$. Scale bar $=10 \mu \mathrm{m}$

(B) Elevated CD36 in the 10-HOME treated naïve T cells. Flow cytometry analyses of treated cells stained with anti-CD4 (FITC) and anti-CD36 (APC). Representative flow plots. (i) vehicle treated (ii) 10-HOME treated (iii) histogram with isotype control for CD36 (iv) \% of $\mathrm{CD}^{+}{ }^{+} \mathrm{CD} 36^{+} \mathrm{T}$ cells. Data presented as mean $\pm S D,(n=7)$.

(C) Increased expression of T-BET in naïve CD4+ $\mathrm{T}$ cells treated with $100 \mu \mathrm{m}$ of 10-HOME compared to vehicle post-48h. T cells were immuno-stained with anti-CD4 (red) antibody, anti- TBET (green) and DAPI (blue). Intensity of TBET quantified for the two groups. Colocalization of CD4 and TBET depicted increased abundance of $\mathrm{CD}^{+}{ }^{+} \mathrm{TBET}^{+}$cells in the breast tissues of Bll subjects. Data presented as mean $\pm S D,(n=6)$. Scale bar $=10 \mu \mathrm{m}$

(D) Elevated Th1 subtype $\left(\mathrm{CD}_{183^{+}}\right)$in the 10 -HOME treated naive $\mathrm{CD} 4^{+} \mathrm{T}$ cells. Flow cytometry analyses of treated cells stained with anti-CD4 (FITC) and anti-CD183 (PE). Representative flow plots. (i) vehicle treated (ii) 10-HOME treated (iii) histogram with isotype control for CD183 (iv) \% of $\mathrm{CD} 4{ }^{+} \mathrm{CD} 183^{+}$. Data presented as mean $\pm \mathrm{SD},(n=7)$.

(E) Increased expression of Th1 secreted pro-inflammatory cytokine IFN- $y$ in the 10-HOME treated naïve $C D 4^{+} T$ cells as measured through ELISA. Data presented as mean $\pm S D(n=7)$.

(F-G) No significant change in the cytokines IL4 and IL10 following10-HOME treatment of naïve CD4+ T cells as measured through ELISA, Data presented as mean $\pm S D,(n=8)$.

(H-I) Increased expression of $(\mathrm{H})$ CD36 (I) T-BET in 10-HOME treated naïve T cells as measured through quantitative real time PCR. Data presented as mean $\pm S D,(n=6)$. 
medRxiv preprint doi: https://doi.org/10.1101/2020.11.18.20233510; this version posted November 20, 2020. The copyright holder for this preprint (which was getcertified by peer review) is the author/funder, who has granted medRxiv a license to display the preprint in perpetuity.

A

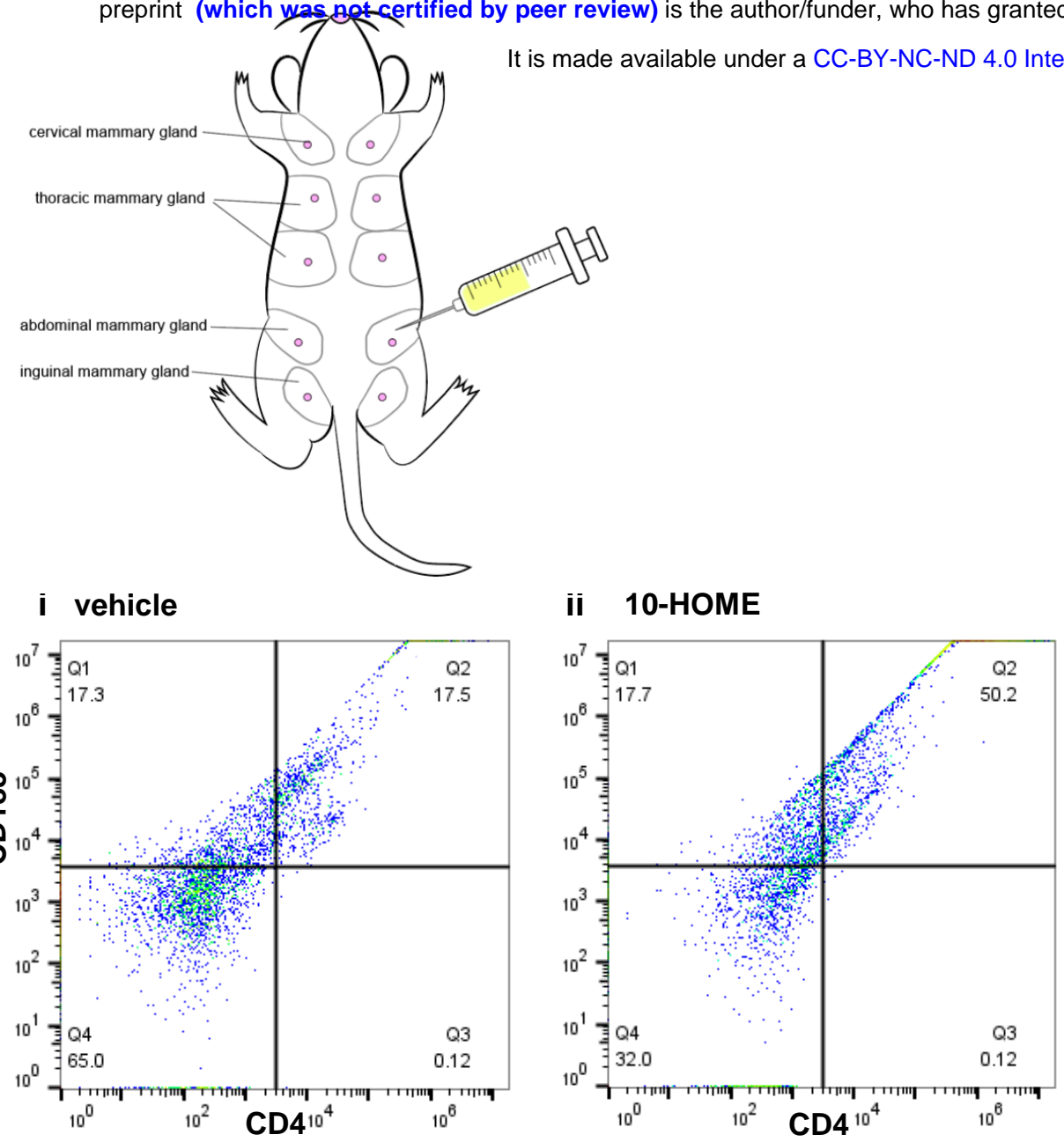

iii

C i vehicle

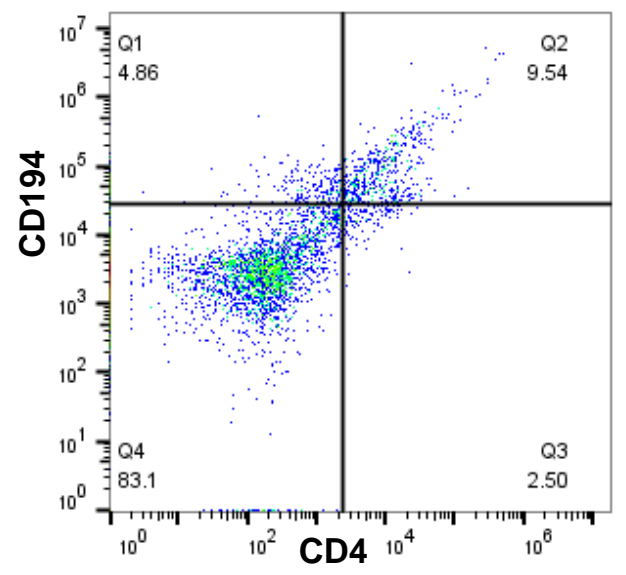

\section{ii 10-HOME}

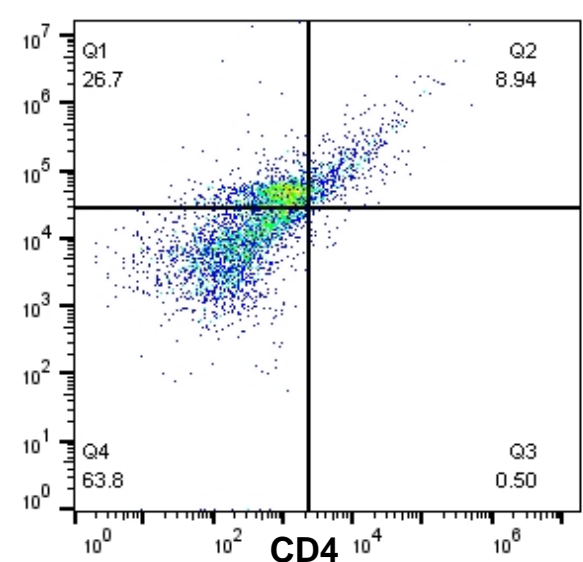

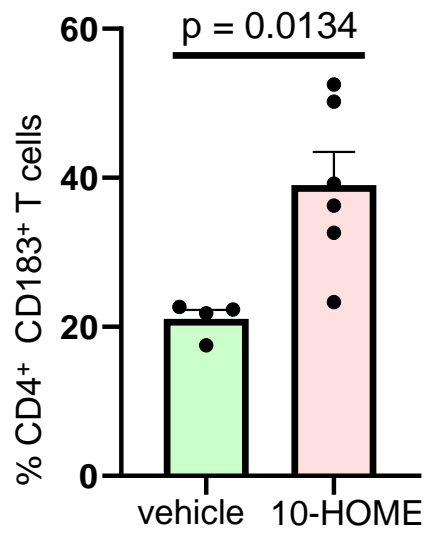

iii

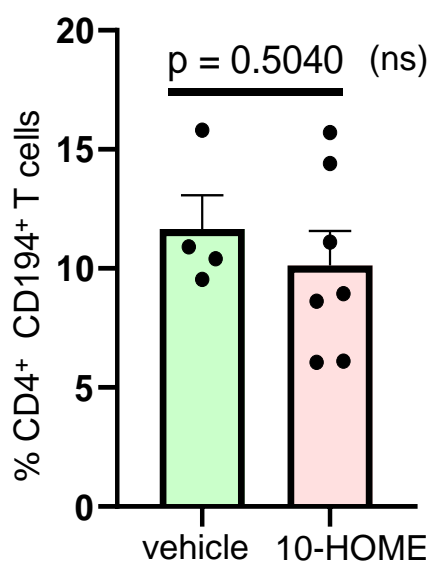


medRxiv preprint doi: https://doi.org/10.1101/2020.11.18.20233510; this version posted November 20, 2020. The copyright holder for this preprint (which was not certified by peer review) is the author/funder, who has granted medRxiv a license to display the preprint in perpetuity.

It is made available under a CC-BY-NC-ND 4.0 International license .

\section{Figure 5. Elevated CD4 ${ }^{+}$Th1 in Peripheral Blood of Mice Administered with 10-HOME}

(A) Schematic representation of injection of 10-HOME in the abdominal mammary fat pad of mice.

(B) Elevated CD4+ Th1 subtype in the blood of mice injected with 10-HOME. Flow cytometry analyses of blood of mice stained with anti-CD4 (FITC) and anti-CD183 (PE). Representative flow plots. (i) Vehicle treated (ii) $10-\mathrm{HOME}$ treated (iii) \% of CD4+ CD183+T cells. Data presented as mean \pm SEM, $(\mathrm{n}=4-6$ mice) .

(C) Unaltered $\mathrm{CD}^{+}$Th2 subtype in the blood of mice injected with 10-HOME. Flow cytometry analyses of blood of mice stained with anti-CD4 (FITC) and anti-CD194 (PE). Representative flow plots. (i) Vehicle treated (ii) $10-\mathrm{HOME}$ treated (iii) \% of $\mathrm{CD} 4^{+} \mathrm{CD} 194^{+} \mathrm{T}$ cells. Data presented as mean \pm SEM, ( $n=4-6$ mice). 